Bull. Geol. Soc. Finland 41, 199-202 (1969)

\title{
ON THE MICROFOSSILS OF CORYCIUM ENIGMATICUM
}

\author{
Arvo Matisto \\ Geological Survey, Otaniemi, Finland
}

\begin{abstract}
This paper deals with alga-like microfossils found in the about 2000 m.y. old schist belt situated $\mathrm{N}$ of Tampere, SW Finland and belonging to the lower Svecofennian. The microfossils occur there in carbon-bearing phyllite and in its inclusions, carbon-bearing slate fragments and carbon sacks, which latter Sederholm regarded as remnants of primitive algae and called Corycium enigmaticum.
\end{abstract}

\section{Introduction}

In 1890 J. J. Sederholm found sack-like carbon-rich structures (Fig. 1) $\mathrm{N}$ of Tampere, SW Finland, in a phyllite, which according to him belonged to the Bothnian formation. He thought the sacks to be remnants of primitive algae and gave them the samewhat tentative name of Corycium enigmaticum (Sederholm 1911).

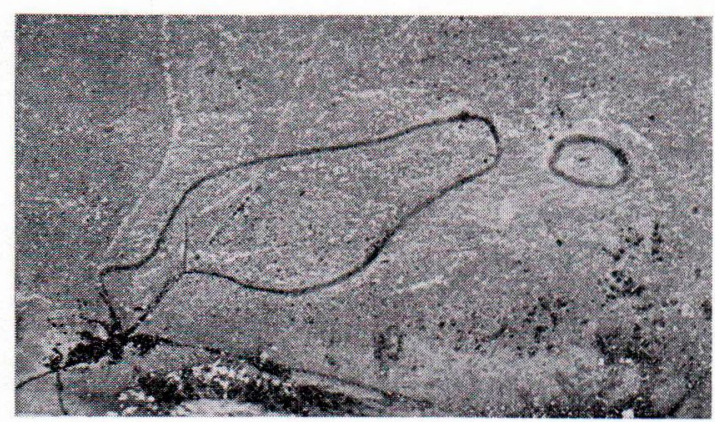

Fig. 1. Corycium enigmaticum. Two typical cross sections on weathered phyllite surface. ${ }^{1 / 3}$ nat. size.
The Bothnian phyllite, the host rock of the Corycium, belongs, according to the latest classification of Finnish Precambrian (Simonen 1960), to the oldest and stratigraphically lowest eogeosynclinal sediment group of the Svecofennidic schist belt. The age of this phyllite is still unknown. As the radiogenic age of the synkinematic plutonic rocks penetrating it is about $1900 \mathrm{~m}$. y. (Kouvo 1958), the age of the sedimentation of the phyllite and hence the age of the Corycium should be estimated as at least $2000 \mathrm{~m}$. y.

Since Sederholm the carbon sacks have been studied by many scientists. Varying opinions have been presented as to the origin of both the structure and the carbon material of Corycium. In this connection it may suffice to mention the extensive study by Rankama (1948) and the papers by Ohlson (1961) and Matisto (1963) together with the Corycium bibliography given in them. The following is a summary of the opinions expressed in the studies on Corycium: 

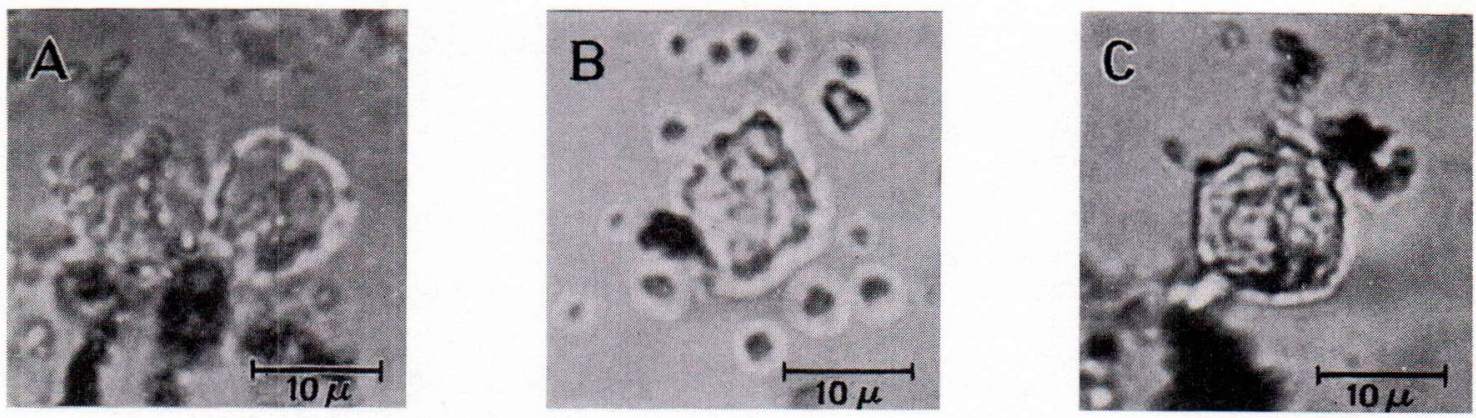

Fig. 2. Single alga-like bodies. A, from Corycium enigmaticum. B, from carbon-bearing slate fragment. C, from carbon-bearing phyllite.
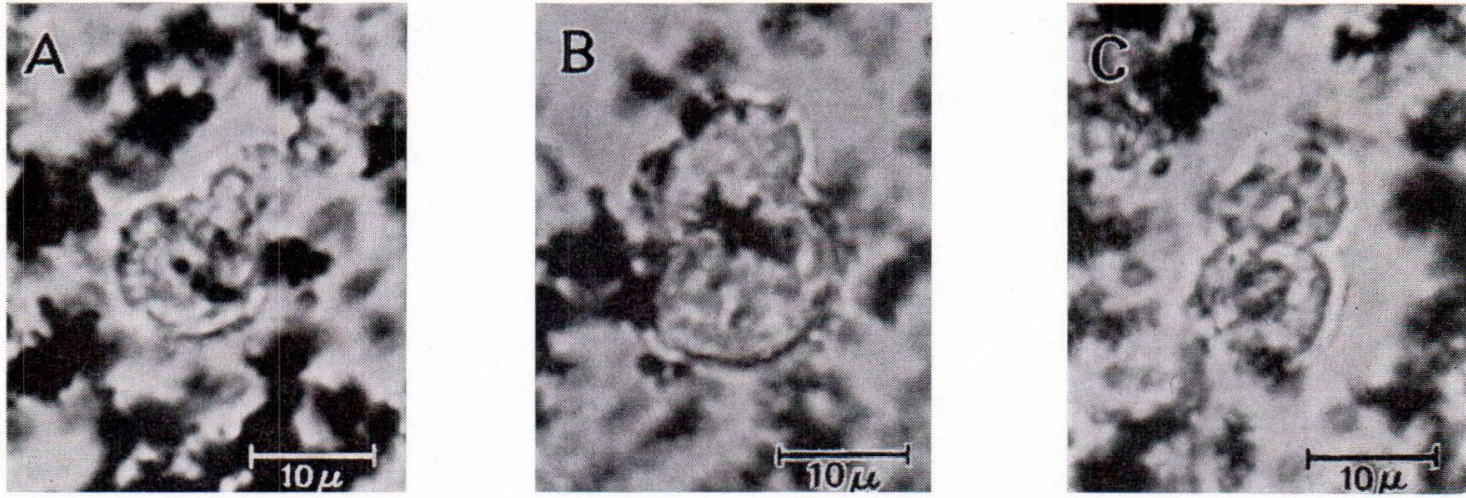

Fig. 3. Double alga-like bodies. A, one normal and one markedly smaller together from Corycium enigmaticum, $\mathrm{B}$, from carbon-bearing slate fragment. C, from carbon-bearing phyllite.

Different biogenic and anorganic modes of origin have been proposed for Corycium. The origin of its structure is still an open question. But even those investigators who have assumed an anorganic origin for the structure of Corycium, do not deny the possible biogenic origin of its carbon. Unquestionable proof of the biogenic origin of the carbon of Corycium has, however, been given only by Rankama (1948), who based his testimonial on the isotope ratio of carbon and on the content of some trace elements, and by Matisto (1963), whose opinion was sustained by the marked $\mathrm{P}_{2} \mathrm{O}_{5}$-content of Corycium.

\section{Microfossils}

Inspired by the pioneering studies of Timofejew the author carried out a number of tests to find out the possible microfossil content of
Corycium. The methods of Timofejew (1959 and 1963) and Tynni (Tynni and Siivola 1966) were adapted for the tests as follows:

The carbon-rich mantle of Corycium was detached from the host rock and crushed and sieved to $>200$ mesh grain size. The powder was boiled in diluted fluoric acid and in 10 percent hydrochloric acid to dissolve the silicate matter. After that glycerine preparates were made and studied under the microscope with 200$1200 \times$ magnification.

The microscopic study revealed that the silicate matter was entirely dissolved, but that the graphitic carbon matter remained. Additionally small spherical bodies, $\varnothing 10 \mu$ on an average, were verified. Sometimes small graphitic flakes were attached to them, but when pure, they were transparent with a violet tinge. They stood out from glycerine mainly on account of their strong 

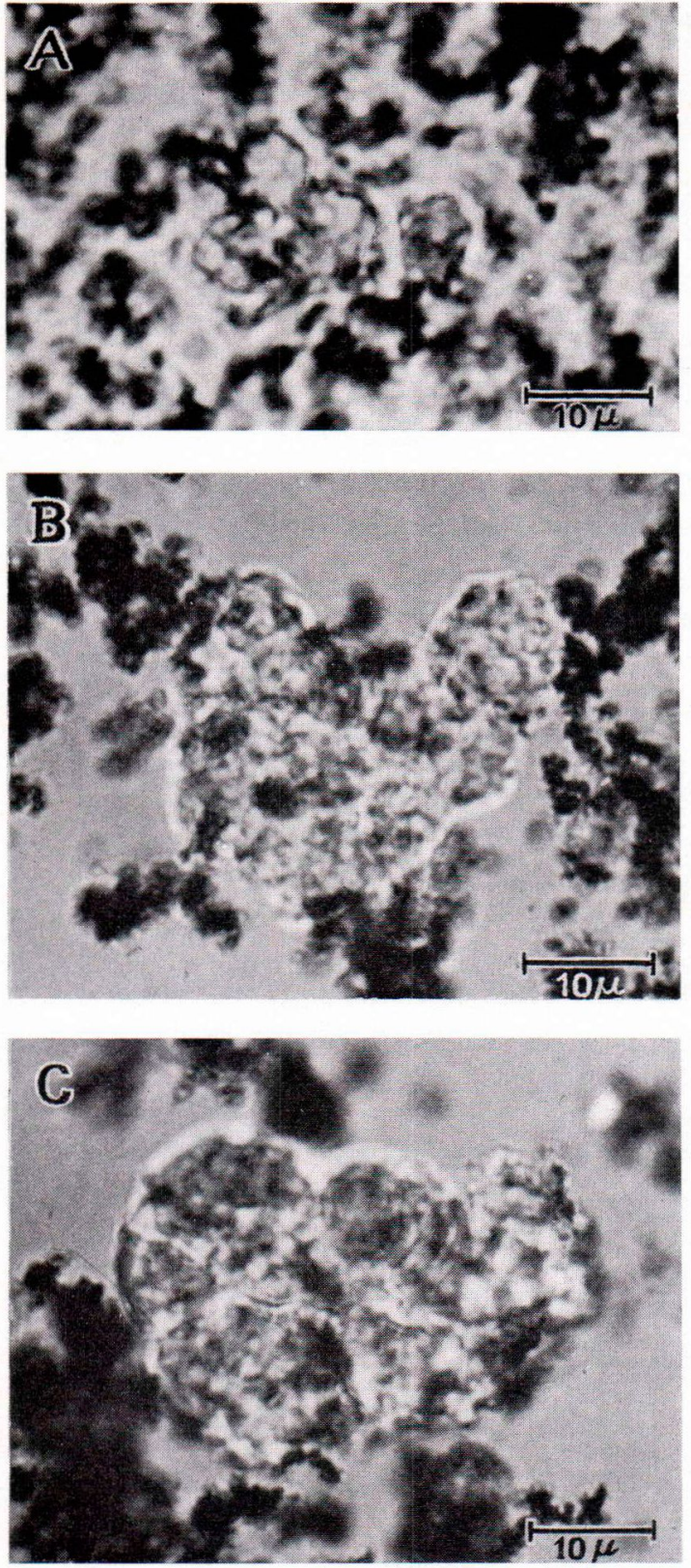

Fig. 4. Alga-like colonies. A, from Corycium enigmaticum. $\mathrm{B}$, from carbon-bearing slate fragment. C, from carbonbearing phyllite.

relief and occasional vaguely concentric inner structure. Their shape was either circular or somewhat angular (Fig. 2).

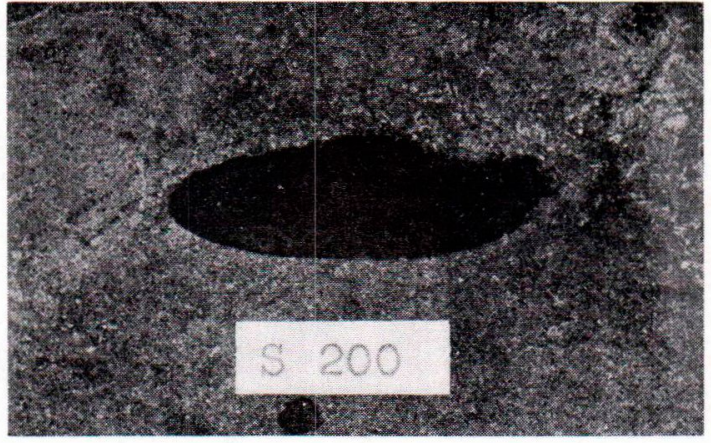

Fig. 5. Carbon-bearing slate fragment from the host rock of Corycium enigmaticum. ${ }^{1 / 1}$.

The preparates even contained 20-30 such bodies. In addition to single bodies all the preparates showed, although much more seldom, double bodies (Fig. 3), among them some with one normal and one markedly smaller body (Fig. $3 \mathrm{~A}$ ), and still fewer body colonies, where the number of bodies varied from 4-15 (Fig. 4). Without exception, both double bodies and body colonies remained attached together when moved in glycerine preparates. This indicates that their combination is a primary feature. It also appeared that the colonies as well as the single bodies are spherical in shape.

Besides the carbon-rich mantle of Corycium also carbon-bearing slate fragments (Fig. 5) in places rather abundant in the host rock and the clayey carbon-bearing top part of the same varved phyllite were studied in the same way. The result was exactly the same as was obtained for the mantle of Corycium (Figs. 2-4). The only difference was, that the slate fragment which was poorer in carbon than the mantle of Corycium contained fewer spheroids and colonies, and the schist which was poorest of all in carbon still fewer. The result agrees completely with the $\mathrm{P}_{2} \mathrm{O}_{5}$-contents of the corresponding objects, which likewise decrease with the diminishing carbon content (Matisto 1963).

So-called blank tests were made to confirm the results. The test material was quartz, but otherwise exactly the same apparatus, vessels and 
reagents were employed as in the tests proper. The results were entirely negative and proved that the spheroids must be derived from the studied objects.

\section{Conclusions}

The facts deduced from the spheroids are scarce. Nothwithstanding the fact that they are somewhat decayed, when their shape, size and appearance are compared with those described in literature (e.g. Timofejew 1959, Barghoorn and Tyler 1965, Cloud 1965, Tynni and Siivola 1966, Licari and Cloud 1968, Engel et al. 1968), it still seems evident that a genuine microfossil is in question. Particularly their size, shape and tendency to appear as spherical colonies indicate them to be algae. This is further confirmed by the fact that corresponding alga-like microfossils have been described before, not only from younger, but also from Precambrian time, some of the latter being younger (e.g. Tynni and Siivola 1966), some contemporaneous (about 2000 m. y.) or older than Corycium (e.g. Glassner 1968). The oldest of all was $3200 \mathrm{~m}$. y. old (Engel et al. 1968). Additionally, the oldest spores identified by Timofejew (1958) were in fact found in the phyllitic host rock of Corycium.

The present study establishes that the alga-like microfossils are mutually identical in all the objects investigated: the phyllite proper and its inclusions, the Corycium and the slate fragments. This proves that the biogenic matter in all of them must have the same origin. This fact is significant when solving the riddle of Corycium and particularly of its sack-like structure. The author would like to be able to return to this question before long.

Acknowledgment - I wish to express my sincere gratitude to Dr. Risto Tynni for the fruitful discussions, which were most helpful in adapting the research methods and identifying the microfossils, to my field and laboratory assistant Mr. Kari Vuorio, and to Mr. Erkki Halme for the published photographs.

\section{REFERENCES}

Barghoorn, E. S. and Tyler, S. A. (1965) Microorganism from the Gunflint chert. Science, Vol. 147, pp. $563-577$.

Cloud, P. E., JR. (1965) Significance of the Gunflint (Precambrian) microflora. Science, Vol. 148, pp. 27 -35 .

Engel, Albert E. J. et al. (1968) Alga-like forms in Onverwacht series, South Africa: Oldest recognized lifelike forms on earth. Science, Vol. 161, pp. 10051008.

Glaessner, M. F. (1968) Biological events and the Precambrian time scale. Canadian Jour. of Earth Sciences, Vol. 5, pp. $585-590$.

Kouvo, Olavi (1958) Radioactive age of some Finnish pre-Cambrian minerals. Bull. Comm. géol. Finlande 182.

Licari, G. R. and Cloud, P. E., JR. (1968) Reproductive structures and taxonomic affinities of some nannafossils from the Gunflint iron formation. Proceedings of the Nat. Acad. of Sciences, Vol. 59, N:o 4, pp. 1053-1060.

Matisto, Arvo (1963) Über den Ursprung des Kohlenstoffes in Corycium. N. Jb. Geol. Paläont., Mh. 8, S. $433-441$.
Ohlson, Birger (1961) Observations on recent lake balls and ancient Corycium inclusions in Finland. C. R. Soc. géol. Finlande 33, pp. 377-390; Bull. Comm. géol. Finlande 196.

Rankama, Kalervo (1948) New evidence of the origin of Pre-Cambrian carbon. Bull. Soc. Geol. Amer. 59, pp. $389-416$.

Sederholm, J. J. (1911) Geologisk öfversiktskarta öfver Finland. Sektionen B 2, Tammerfors. Beskrifning till bergartskartan (Résumé en Français).

Simonen, Ahti (1960) Pre-Quaternary rocks in Finland. Bull. Comm. géol. Finlande 191.

Trmofejew, B. W. (1958) Über das Alter sächsischer Grauwacken. Geologie, Jg. 7, H. 3-6, S. 826-845.

- (1959) Древнейшая флора Прибалтики и ее стратиграфическое значение. [The oldest Baltic flora and its stratigraphical significance]. Труды ВНИГРИ, выш. 129. Ленинград.

- (1963) On organic remains in the Eocambrian of Norway. Norsk Geol. Tidskr., part 4, pp. 473-476.

Tynni, Risto and Sirvola, JaAkko (1966) On the Precambrian microfossil flora in the siltstone of Muhos, Finland. C. R. Soc. géol. Finlande 38, pp. 127-133. Manuscript received, January 31, 1969. 